\title{
Individual use of antiasthmatic drugs in the European Community Respiratory Health Survey
}

\author{
C. Janson+, S. Chinn*, D. Jarvis*, P. Burney*, \\ on behalf of the European Community Respiratory Health Survey
}

\begin{abstract}
Individual use of antiasthmatic drugs in the European Community Respiratory Health Survey. C. Janson, S. Chinn, D. Jarvis, P. Burney, on behalf of the European Community Respiratory Health Survey. CERS Journals Ltd 1998.

ABSTRACT: A previous analysis of drug utilization in the European Community Respiratory Health Survey found that only between 8 and $29 \%$ of subjects with asthma-related symptoms were using antiasthmatic medication in the different areas studied. The aim of this analysis was to investigate which variables were related to individual use of antiasthmatic medication in different geographical areas.

Thirty-three centres in 14 countries were analysed, in which a total of 16,854 people (52.1\% females, mean age 33.8 yrs, range 20-48) underwent a structured interview, measurement of specific immunoglobin $E$, spirometry and methacholine challenge test.

The use of antiasthmatic drugs in individuals was, in most countries, independently related to asthma-related respiratory symptoms, bronchial hyperresponsiveness (BHR) and atopy. In all countries smokers with respiratory symptoms were less likely to be using antiasthmatic drugs than nonsmokers and exsmokers. In four of 14 countries females were significantly more likely to use antiasthmatic medication than males, while age and socioeconomic status were unrelated to medication. The use of inhaled anti-inflammatory drugs was positively related to symptoms, BHR and atopy and negatively related to current smoking.

In conclusion, in many countries smokers were less likely to be using antiasthmatic drugs than were nonsmokers with comparable levels of symptoms and bronchial hyperresponsiveness. Age and socioeconomic status were unrelated to medication, while in some countries females were more likely than males to use antiasthmatic medication.

Eur Respir J 1998; 12: 557-563.
\end{abstract}

${ }^{+}$Dept Lung Medicine, Akademisha Sjukhuset, Uppsala, Sweden. *Dept of Public Health Medicine, UMDS, London, UK.

Correspondence: P. Burney

Dept of Public Health Medicine

United Medical and Dental Schools of

Guy's and St Thomas's Hospitals

42 Weston Street

London SE1 3QD

UK

Fax: 441714034602

Keywords: Asthma

atopy

bronchial hyperresponsiveness

drug utilization

smoking

socioeconomic status

Received: December 41997

Accepted after revision May 121998
Since 1990 information on the variation in asthma prevalence, known or suspected risk factors for atopy and asthma and information on the management of asthma has been collected in the European Community Respiratory Health Survey (ECRHS) [1-6]. Results from the study so far have shown that there is a considerable geographical variation in the prevalence of respiratory symptoms [3], as well as a variation in the prevalence of atopic sensitization [4] and bronchial hyperresponsiveness (BHR) [5].

There has been a considerable increase in the use of antiasthmatic medication in many countries during the last few decades [7-10]. Analysis of drug sales shows considerable differences between countries in the sale of antiasthmatic drugs $[11,12]$. Analysis of data from the ECRHS confirmed that there is wide geographical variation in the use of antiasthmatic medication [6]. In that analysis it was found that the use of antiasthmatic medication in subjects with asthma related-symptoms varied from $8-29 \%$ in the different geographical areas studied.

The aim of this analysis was to investigate which variables were related to individual use of antiasthmatic medication in different countries.
Population and methods

\section{Selection of population}

The methods used in the ECRHS have been described before $[1,2]$. Participating centres selected areas for study, which were defined by pre-existing administrative boundaries, had populations of at least 150,000 inhabitants and, where possible, had up-to-date sampling frames of 20-44 yr olds.

Stage 1 . In the first phase of the study randomly selected samples of at least 1,500 people of each sex were sent questionnaires enquiring about respiratory symptoms, attacks of asthma, use of asthma medication and hay fever or nasal allergies, together with questions checking the date of birth and sex of the respondents.

Stage 2. In the second part of the study a random sample of those selected for the first stage were invited to come for 
a structured interview, blood test, skin tests, assessment of lung function by spirometry and airway challenge with methacholine. Detailed information on medication used to help breathing and use of healthcare services because of breathing problems was collected during the interview.

At the time of this analysis (October 1996), 48 centres from 22 countries had participated in the first phase of the study while 36 centres from 16 countries had completed the second phase and had their data checked by the coordinating centre. In this analysis only the 33 centres from 14 countries that provided data from both the questionnaire and methacholine challenge as well as specific immunoglobin $(\mathrm{Ig}) \mathrm{E}$ measurements were included.

\section{Asthma-related variables}

Antiasthmatic medication was defined as reporting having taken one or more of the following drugs in the previous 12 months. Inhaled bronchodilators, which included: 1) $\beta_{2}$-agonists, 2) nonspecific adrenoreceptor agonists, 3) anticholinergic agents, and 4) compound bronchodilators. Inhaled anti-inflammatory medication, which included: 1) inhaled steroids, 2) sodium cromoglycate and nedocromil sodium, and 3) compound bronchodilators containing steroids or sodium cromoglycate. Oral antiasthmatic medication, which included: 1) $\beta_{2}$-agonists, 2) theophylline, 3) ketotifen, 4) compound bronchodilators, and 5) oral corticosteroids taken because of breathing problems.

Asthma-related symptoms were defined as having had the following symptoms in the previous 12 months: 1) wheezing or whistling in the chest; 2) wheezing in combination with breathlessness, and wheezing when not having a cold; 3) having been woken with a feeling of chest tightness or by an attack of shortness of breath; and 4) having had an attack of shortness of breath that came during the day when at rest or following strenuous activity. The number of asthma-related symptoms was calculated $[13,14]$. In this analysis the subjects were categorized into three groups by symptoms: no symptom, one or two symptoms and at least three symptoms.

Physician-diagnosed asthma was defined as reporting: 1) ever having had asthma where the diagnosis had been confirmed by a doctor, and 2) having at least one asthma related symptom in the last 12 months $[6,14]$.

Subjects were also asked: 1) whether they had ever been seen by a doctor because of breathing problems or because of shortness of breath and, if yes, 2) when was the last time they had been seen by a doctor. Subjects were categorized in two groups: those who had been seen by a doctor because of breathing problems within the last 12 months and those who had not.

Lung function and methacholine challenge tests were carried out according to the ECRHS study protocol [1,2]. Forced expiratory volume in one second (FEV1) was measured and the predicted values were calculated for each subject [15]. In this analysis FEV1 was expressed as a percentage of the predicted value. Methacholine challenge was carried out using a dosimeter (Mefar, Brescia, Italy) $[1,2]$. BHR was, in this analysis, defined as a decrease in FEV1 by at least $20 \%$ after the inhalation of 1 mg methacholine or less.

Specific IgE was measured using the Pharmacia CAP System (Pharmacia Diagnostics, Uppsala, Sweden) [4]. In all centres specific IgE was measured against Dermatophagoides pteronyssinus, timothy grass, cat, Cladosporium herbarum and a local allergen. The local allergen was birch for northern Europe, Parietaria judaica for southern Europe and ragweed for the USA, New Zealand and Australia. In this analysis atopy was defined as detection of specific $\operatorname{IgE}\left(>0.35 \mathrm{kU} \cdot \mathrm{L}^{-1}\right)$ against any of the tested allergens.

\section{Personal and social variables}

The participants were asked whether they had smoked at least one cigarette.day-1, one cigar a week for $1 \mathrm{yr}$ or $360 \mathrm{~g}$ tobacco in a lifetime. The subjects were categorized into three groups: nonsmokers, exsmokers and current smokers. Current smokers were defined as those who had smoked within the last month.

The European Community Status Groups were used for the socioeconomic classification, which comprised 14 groups [16]. In this analysis socioeconomic status was categorized in three groups: 1) professionals, semiprofessionals and supervisors of manual work (groups 1, 3-9 and 11),2) manual workers, clerical and service workers (groups 2, 10 and 12), and 3) others (groups 13, 14 and unclassified).

\section{Statistics}

The statistical analysis was performed using SAS (SAS Institute, Cary, NC, USA) and generalized linear interactive model (GLIM) [17]. Chi-squared tests were used in the univariate analyses. Logistic regression was used when calculating odds ratios for the influence of independent variables on the prevalence of antiasthmatic medication. This analysis was carried out by country, including centre within country as one of the independent variables. We investigated whether centre interacted with any of the other independent variables, but no significant centre interaction was found within any country.

Adjusted prevalences of antiasthmatic medication were calculated by taking into account the nonparticipation rate and the characteristics of the nonrespondents in stage 2 . The age, sex and symptomatology of the responders and nonresponders were known from the screening questionnaire in stage 1 and the adjusted prevalence estimate made the assumption that the nonresponders had the same prevalence of diagnosed asthma and antiasthmatic medication as responders of the same age and sex group, living in the same centre with the same symptoms reported in the screening questionnaire $[4,6]$.

\section{Results}

The total number of participants in the random sample was 16,854 (52.1\% females, mean age 33.8 yrs, range 2048). The participation rate varied from $90 \%$ in Umeå, Sweden, to $12 \%$ in Montpellier, France, while the adjusted prevalence for use of antiasthmatic medication in the last 12 months varied from 16\% in Melbourne, Australia, to $1.5 \%$ in Galdakao, Spain [6] (table 1). The number of 
Table 1. - Number of participants, response rates and the adjusted prevalences of use of antiasthmatic medication in stage 2

\begin{tabular}{|c|c|c|c|c|c|}
\hline $\begin{array}{l}\text { Country } \\
\text { Years of } \\
\text { examination }\end{array}$ & Centre & $\begin{array}{c}\text { Random } \\
\text { sample } \\
\text { n }\end{array}$ & $\begin{array}{c}\text { Response } \\
\text { rate } \\
\%\end{array}$ & $\begin{array}{c}\text { Antiasthmatic } \\
\text { asthmatic } \\
\text { medication } \\
\%\end{array}$ & $\begin{array}{c}\text { Inhaled anti- } \\
\text { inflammatory } \\
\text { medication } \\
\%\end{array}$ \\
\hline $\begin{array}{l}\text { Iceland } \\
\text { 1991-92 }\end{array}$ & Reykjavik & 559 & 83.2 & 3.4 & 1.0 \\
\hline $\begin{array}{l}\text { Norway } \\
1992-93\end{array}$ & Bergen & 835 & 87.1 & 3.6 & 1.4 \\
\hline \multirow[t]{2}{*}{ 1991-92 } & Umeå & 552 & 90.3 & 8.7 & 2.3 \\
\hline & Uppsala & 622 & 87.7 & 6.8 & 1.9 \\
\hline $\begin{array}{l}\text { Ireland } \\
1992-93\end{array}$ & Dublin & 437 & 73.0 & 6.9 & 2.8 \\
\hline UK & Cambridge & 277 & 52.6 & 9.6 & 6.5 \\
\hline Netherlands & Groningen & 380 & 63.4 & 4.5 & 1.5 \\
\hline \multirow{2}{*}{ 1992-93 } & Bergen-op-Zoom & 452 & 70.8 & 5.8 & 2.5 \\
\hline & Geleen & 413 & 61.8 & 3.8 & 1.2 \\
\hline Belgium & South Antwerp & 577 & 72.1 & 5.0 & 1.6 \\
\hline 1991-92 & Antwerp City & 562 & 64.8 & 5.8 & 2.6 \\
\hline France & Bordeaux & 544 & 18.5 & 7.6 & 3.2 \\
\hline \multirow[t]{3}{*}{ 1991-93 } & Grenoble & 473 & 40.6 & 11.1 & 3.2 \\
\hline & Montpellier & 456 & 12.2 & 8.8 & 3.4 \\
\hline & Paris & 652 & 20.9 & 6.2 & 1.4 \\
\hline Spain & Barcelona & 393 & 73.6 & 3.3 & 1.2 \\
\hline 1991-93 & Galdakao & 486 & 84.4 & 1.5 & 0.8 \\
\hline New Zealand & Wellington & 481 & 64.9 & 14.8 & 8.2 \\
\hline \multirow[t]{2}{*}{ 1991-93 } & Christchurch & 455 & 63.7 & 15.1 & 6.9 \\
\hline & Hawkes Bay & 316 & 57.6 & 12.1 & 7.7 \\
\hline $\begin{array}{l}\text { Australia } \\
1992-94\end{array}$ & Melbourne & 669 & 40.7 & 16.0 & 6.7 \\
\hline
\end{tabular}

participants that participated in spirometry were 14,040 , while 12,286 participated in the methacholine test and specific IgE measurements were available from 12,692 subjects.

\section{Analysis of individual use of antiasthmatic medication}

Univariate analysis showed that in all countries antiasthmatic medication in the last 12 months was significantly related to asthma-related symptoms, BHR and atopy. In all countries except for Italy and Iceland mean FEV1 was significantly lower in subjects that had used antiasthmatic medication than in subjects without treatment. In France a higher socioeconomic status was related to a lower prevalence of antiasthmatic medication (8.2 versus 12.3 and $14.0 \%, \mathrm{p}<0.01)$. Otherwise, no relation between socioeconomic status and use of antiasthmatic medication was found in the univariate analysis.

Logistic regression showed that in all countries the use of antiasthmatic medication was positively related to re- porting respiratory symptoms and BHR. A significant independent relation between atopy and medication was also found in eight of the 14 countries (table 2). An independent significant relation to $\mathrm{FEV}_{1}$ ( $\%$ predicted) was only found in the Netherlands (adjusted odds ratio (OR) $(95 \%$ confidence intervals $(\mathrm{CI}))=1.7(1.3-2.3)$ with each $10 \%$ decrease).

In most countries females were more likely than males to report taking antiasthmatic medication and this reached statistical significance in Ireland, France, Italy and New Zealand. In all countries current smokers were less likely to use antiasthmatic medication, with the association being significant in seven of the 14 countries (table 2). There was no consistent association between exsmoking and the use of antiasthmatic treatment. In Iceland the probability of being treated increased with age (adjusted OR $=2.4$, CI 1.4-4.1, for each $5 \mathrm{yr}$ increase in age) but otherwise there was no significant association between age and treatment. No independent significant correlation between socioeconomic status and taking antiasthmatic medication was found. 
Table 2. - Influence of respiratory symptoms, bronchial hyperresponsiveness (BHR) and atopy on the use of antiasthmatic medication after adjustment for centre, age, sex, smoking, socioeconomic status and each of the other independent variables in the table

\begin{tabular}{|c|c|c|c|c|c|c|c|}
\hline Country & $\mathrm{n}$ & $\begin{array}{l}\text { Females in } \\
\text { relation to } \\
\text { males }\end{array}$ & $\begin{array}{l}\text { Exsmoker in } \\
\text { relation to } \\
\text { never }\end{array}$ & $\begin{array}{l}\text { Smoker in } \\
\text { relation to } \\
\text { never }\end{array}$ & $\begin{array}{l}\text { Symptoms } \\
\text { (at least three) } \\
\text { in relation } \\
\text { to none }\end{array}$ & $\begin{array}{l}\text { BHR in } \\
\text { in relation } \\
\text { to none }\end{array}$ & $\begin{array}{l}\text { Atopy } \\
\text { in relation } \\
\text { to none }\end{array}$ \\
\hline Iceland & 454 & $\begin{array}{c}1.1 \\
(0.3-4.5)\end{array}$ & $\begin{array}{c}0.2 \\
(0.02-2.0)\end{array}$ & $\begin{array}{c}0.7 \\
(0.2-3.2)\end{array}$ & $\begin{array}{c}98 \\
(14-706)\end{array}$ & $\begin{array}{c}2.4 \\
(0.5-13)\end{array}$ & $\begin{array}{c}5.8 \\
(1.5-23)\end{array}$ \\
\hline Norway & 539 & $\begin{array}{c}0.9 \\
(0.2-3.6)\end{array}$ & $\begin{array}{c}0.7 \\
(0.1-4.4)\end{array}$ & $\begin{array}{c}0.2 \\
(0.05-0.9)\end{array}$ & $\begin{array}{c}35 \\
(5.6-215)\end{array}$ & $\begin{array}{c}4.8 \\
(1.1-21)\end{array}$ & $\begin{array}{c}2.3 \\
(0.6-8.9)\end{array}$ \\
\hline Sweden & 1313 & $\begin{array}{c}1.4 \\
(0.8-2.5)\end{array}$ & $\begin{array}{c}1.8 \\
(0.9-3.5)\end{array}$ & $\begin{array}{c}0.4 \\
(0.2-0.8)\end{array}$ & $\begin{array}{c}106 \\
(43-259)\end{array}$ & $\begin{array}{c}3.5 \\
(1.9-6.5)\end{array}$ & $\begin{array}{c}3.2 \\
(1.8-5.5)\end{array}$ \\
\hline Ireland & 203 & $\begin{array}{c}4.9 \\
(1.04-23)\end{array}$ & $\begin{array}{c}2.0 \\
(0.4-11)\end{array}$ & $\begin{array}{c}0.3 \\
(0.05-1.8)\end{array}$ & $\begin{array}{c}7.2 \\
(1.3-40)\end{array}$ & $\begin{array}{c}5.0 \\
(1.4-18)\end{array}$ & $\begin{array}{c}3.4 \\
(0.9-13)\end{array}$ \\
\hline UK & 743 & $\begin{array}{c}1.2 \\
(0.5-2.7)\end{array}$ & $\begin{array}{c}1.2 \\
(0.4-3.0)\end{array}$ & $\begin{array}{c}0.2 \\
(0.1-0.5)\end{array}$ & $\begin{array}{c}324 \\
(85->999)\end{array}$ & $\begin{array}{c}4.3 \\
(1.9-10)\end{array}$ & $\begin{array}{c}2.4 \\
(1.02-5.5)\end{array}$ \\
\hline Germany & 1312 & $\begin{array}{c}0.7 \\
(0.3-1.6)\end{array}$ & $\begin{array}{c}0.7 \\
(0.2-2.0)\end{array}$ & $\begin{array}{c}0.4 \\
(0.2-1.1)\end{array}$ & $\begin{array}{c}64 \\
(18-226)\end{array}$ & $\begin{array}{c}9.7 \\
(4.3-22)\end{array}$ & $\begin{array}{c}1.7 \\
(0.8-3.8)\end{array}$ \\
\hline Netherlands & 1001 & $\begin{array}{c}2.1 \\
(0.97-4.5)\end{array}$ & $\begin{array}{c}0.6 \\
(0.2-2.0)\end{array}$ & $\begin{array}{c}0.6 \\
(0.3-1.4)\end{array}$ & $\begin{array}{c}92 \\
(25-336)\end{array}$ & $\begin{array}{c}5.7 \\
(2.7-12)\end{array}$ & $\begin{array}{c}1.3 \\
(0.6-2.7)\end{array}$ \\
\hline Belgium & 515 & $\begin{array}{c}0.8 \\
(0.3-2.2)\end{array}$ & $\begin{array}{c}1.7 \\
(0.5-5.5)\end{array}$ & $\begin{array}{c}0.3 \\
(0.1-0.99)\end{array}$ & $\begin{array}{c}31 \\
(5.5-170)\end{array}$ & $\begin{array}{c}4.7 \\
(1.6-13)\end{array}$ & $\begin{array}{c}1.6 \\
(0.6-4.2)\end{array}$ \\
\hline France & 1537 & $\begin{array}{c}1.6 \\
(1.04-2.4)\end{array}$ & $\begin{array}{c}1.0 \\
(0.6-1.6)\end{array}$ & $\begin{array}{c}0.6 \\
(0.4-0.9)\end{array}$ & $\begin{array}{c}7.9 \\
(4.3-14)\end{array}$ & $\begin{array}{c}2.9 \\
(1.8-4.6)\end{array}$ & $\begin{array}{c}2.3 \\
(1.5-3.6)\end{array}$ \\
\hline Spain & 1087 & $\begin{array}{c}1.1 \\
(0.5-2.1)\end{array}$ & $\begin{array}{c}1.0 \\
(0.4-2.3)\end{array}$ & $\begin{array}{c}0.2 \\
(0.1-0.5)\end{array}$ & $\begin{array}{c}14 \\
(5.6-35)\end{array}$ & $\begin{array}{c}2.4 \\
(1.1-5.2)\end{array}$ & $\begin{array}{c}2.3 \\
(1.1-4.6)\end{array}$ \\
\hline Italy & 627 & $\begin{array}{c}2.8 \\
(1.1-7.6)\end{array}$ & $\begin{array}{c}0.9 \\
(0.3-2.5)\end{array}$ & $\begin{array}{c}0.5 \\
(0.2-1.6)\end{array}$ & $\begin{array}{c}4.6 \\
(0.98-22)\end{array}$ & $\begin{array}{c}2.0 \\
(0.7-6.0)\end{array}$ & $\begin{array}{c}4.1 \\
(1.5-11)\end{array}$ \\
\hline USA & 270 & $\begin{array}{c}0.6 \\
(0.2-1.2)\end{array}$ & $\begin{array}{c}2.9 \\
(1.03-7.9)\end{array}$ & $\begin{array}{c}1.0 \\
(0.4-2.8)\end{array}$ & $\begin{array}{c}9.1 \\
(2.8-29)\end{array}$ & $\begin{array}{c}2.0 \\
(0.7-5.4)\end{array}$ & $\begin{array}{c}2.6 \\
(1.1-6.5)\end{array}$ \\
\hline New Zealand & 529 & $\begin{array}{c}2.4 \\
(1.2-4.7)\end{array}$ & $\begin{array}{c}1.0 \\
(0.5-2.2)\end{array}$ & $\begin{array}{c}0.3 \\
(0.1-0.8)\end{array}$ & $\begin{array}{c}27 \\
(11-68)\end{array}$ & $\begin{array}{c}3.5 \\
(1.8-6.8)\end{array}$ & $\begin{array}{c}2.2 \\
(1.2-4.4)\end{array}$ \\
\hline Australia & 472 & $\begin{array}{c}1.4 \\
(0.8-2.4)\end{array}$ & $\begin{array}{c}1.4 \\
(0.7-2.7)\end{array}$ & $\begin{array}{c}0.5 \\
(0.3-1.1)\end{array}$ & $\begin{array}{c}10 \\
(4.9-20)\end{array}$ & $\begin{array}{c}2.0 \\
(1.1-3.7)\end{array}$ & $\begin{array}{c}1.6 \\
(0.9-2.9)\end{array}$ \\
\hline
\end{tabular}

Data are shown as adjusted odds ratio (95\% confidence interval).

\section{Inhaled anti-inflammatory medication}

In 10 out of 14 countries inhaled anti-inflammatory drugs were used by a sufficient number of persons to examine which variables predicted the use of inhaled antiinflammatory medication by logistic regression (table 3 ). Use of anti-inflammatory medication was positively related to the level of asthma symptoms, BHR and atopy. In all countries there was a negative association between current smoking and the use of anti-inflammatory medication. There was variation between countries in the association between female sex and the use of anti-inflammatory drugs.

\section{Smoking and the use of antiasthmatic medication}

In most countries nonsmokers with symptoms (at least three symptoms) had a significantly higher prevalence of use of antiasthmatic medication and physician-diagnosed asthma than smokers with symptoms (table 4). In the Spanish, Swedish and French areas nonsmokers also had a significantly higher prevalence of doctor consultations within the last 12 months than smokers with asthma-related symptoms.

Among those with physician-diagnosed asthma, nonsmokers in Australia, Spain and France were significantly more likely to be using antiasthmatic medication than smokers (table 5). Among those who had consulted a doctor in the previous 12 months because of breathing problems, nonsmokers in Australia and France were also significantly more likely than smokers to be taking antiasthmatic medication.

\section{Discussion}

The aim of this analysis was to investigate which variables were related to individual use of antiasthmatic medication in different geographical areas. The use of antiasthmatic drugs in individuals was positively related to respiratory symptoms, BHR and atopy and negatively related to current smoking.

In the present analysis, smokers were less likely to report taking antiasthmatic drugs than nonsmokers with comparable levels of symptoms and BHR. Symptomatic smokers were also less likely to have a diagnosis of asthma. In many countries smokers with symptoms also had fewer doctor consultations because of breathing problems than symptomatic nonsmokers. Among both those with diagnosed asthma and those who had consulted a doctor with breathing problems, smokers were less likely than nonsmokers to be using asthma medication.

There are several possible explanations as to why smokers with symptoms are less likely than nonsmokers to be diagnosed as having asthma and prescribed antiasthmatic drugs. It has been suggested that asthmatic patients often 
Table 3. - Influence of sex, smoking, respiratory symptoms, bronchial hyperresponsiveness (BHR) and atopy on the use of inhaled anti-inflammatory medication after adjustment for centre, age and each of the other independent variables in the table

\begin{tabular}{|c|c|c|c|c|c|c|}
\hline Country & $\begin{array}{l}\text { Females in } \\
\text { relation to } \\
\text { males }\end{array}$ & $\begin{array}{l}\text { Exsmoker in } \\
\text { relation to } \\
\text { never }\end{array}$ & $\begin{array}{l}\text { Smoker in } \\
\text { relation to } \\
\text { never }\end{array}$ & $\begin{array}{c}\text { Symptoms } \\
\text { (at least three) } \\
\text { in relation } \\
\text { to none }\end{array}$ & $\begin{array}{l}\text { BHR in } \\
\text { in relation } \\
\text { to none }\end{array}$ & $\begin{array}{l}\text { Atopy } \\
\text { in relation } \\
\text { to none }\end{array}$ \\
\hline Sweden & $\begin{array}{c}0.9 \\
(0.4-2.2)\end{array}$ & $\begin{array}{c}0.3 \\
(0.1-1.2)\end{array}$ & $\begin{array}{c}0.4 \\
(0.1-1.2)\end{array}$ & $\begin{array}{c}29 \\
(7.4-115)\end{array}$ & $\begin{array}{c}4.0 \\
(1.6-10)\end{array}$ & $\begin{array}{c}1.9 \\
(0.8-4.8)\end{array}$ \\
\hline Ireland & $\begin{array}{c}2.2 \\
(0.3-18)\end{array}$ & $\begin{array}{c}0.4 \\
(0.02-6.0)\end{array}$ & $\begin{array}{c}0.02 \\
(0.001-0.8)\end{array}$ & $\begin{array}{c}8.6 \\
(0.8-101)\end{array}$ & $\begin{array}{c}8.1 \\
(0.98-66)\end{array}$ & $\begin{array}{c}7.1 \\
(0.7-7.3)\end{array}$ \\
\hline UK & $\begin{array}{c}0.8 \\
(0.3-1.9)\end{array}$ & $\begin{array}{c}2.7 \\
(0.9-8.0)\end{array}$ & $\begin{array}{c}0.5 \\
(0.2-1.6)\end{array}$ & $\begin{array}{c}117 \\
(15-949)\end{array}$ & $\begin{array}{c}2.3 \\
(0.8-6.3)\end{array}$ & $\begin{array}{c}1.3 \\
(0.5-3.6)\end{array}$ \\
\hline Germany & $\begin{array}{c}4.9 \\
(0.9-27)\end{array}$ & $\begin{array}{c}2.0 \\
(0.3-12)\end{array}$ & $\begin{array}{c}0.5 \\
(0.2-1.6)\end{array}$ & $\begin{array}{c}55 \\
(5.1-598)\end{array}$ & $\begin{array}{c}5.0 \\
(1.2-22)\end{array}$ & $\begin{array}{c}1.0 \\
(0.2-4.2)\end{array}$ \\
\hline France & $\begin{array}{c}2.0 \\
(0.99-3.8)\end{array}$ & $\begin{array}{c}1.0 \\
(0.4-2.2)\end{array}$ & $\begin{array}{c}0.9 \\
(0.4-1.9)\end{array}$ & $\begin{array}{c}5.7 \\
(2.4-13)\end{array}$ & $\begin{array}{c}2.2 \\
(1.1-4.6)\end{array}$ & $\begin{array}{c}1.7 \\
(0.8-3.4)\end{array}$ \\
\hline Spain & $\begin{array}{c}2.3 \\
(0.99-5.5)\end{array}$ & $\begin{array}{c}1.1 \\
(0.4-3.1)\end{array}$ & $\begin{array}{c}0.2 \\
(0.1-0.6)\end{array}$ & $\begin{array}{c}14 \\
(4.9-41)\end{array}$ & $\begin{array}{c}1.4 \\
(0.5-3.8)\end{array}$ & $\begin{array}{c}2.6 \\
(1.1-6.0)\end{array}$ \\
\hline Italy & $\begin{array}{c}2.3 \\
(0.7-7.2)\end{array}$ & $\begin{array}{c}1.4 \\
(0.4-4.8)\end{array}$ & $\begin{array}{c}0.5 \\
(0.1-2.2)\end{array}$ & $\begin{array}{c}2.7 \\
(0.3-28)\end{array}$ & $\begin{array}{c}1.2 \\
(0.3-4.7)\end{array}$ & $\begin{array}{c}3.4 \\
(1.04-11)\end{array}$ \\
\hline USA & $\begin{array}{c}0.6 \\
(0.2-1.5)\end{array}$ & $\begin{array}{c}2.1 \\
(0.7-6.0)\end{array}$ & $\begin{array}{c}0.8 \\
(0.2-2.9)\end{array}$ & $\begin{array}{c}3.3 \\
(0.98-11)\end{array}$ & $\begin{array}{c}1.4 \\
(0.5-4.1)\end{array}$ & $\begin{array}{c}3.0 \\
(1.2-5.8)\end{array}$ \\
\hline New Zealand & $\begin{array}{c}2.8 \\
(1.3-6.1)\end{array}$ & $\begin{array}{c}0.8 \\
(0.3-1.8)\end{array}$ & $\begin{array}{c}0.3 \\
(0.1-0.9)\end{array}$ & $\begin{array}{c}15 \\
(5.3-43)\end{array}$ & $\begin{array}{c}1.7 \\
(0.8-3.7)\end{array}$ & $\begin{array}{c}2.7 \\
(1.2-5.8)\end{array}$ \\
\hline Australia & $\begin{array}{c}1.4 \\
(0.7-3.0)\end{array}$ & $\begin{array}{c}2.1 \\
(0.9-4.6)\end{array}$ & $\begin{array}{c}0.4 \\
(0.1-1.4)\end{array}$ & $\begin{array}{c}4.9 \\
(1.9-13)\end{array}$ & $\begin{array}{c}2.7 \\
(1.2-6.0)\end{array}$ & $\begin{array}{c}1.8 \\
(0.8-4.0)\end{array}$ \\
\hline
\end{tabular}

Data are shown as adjusted odds ratio (95\% confidence interval).

quit smoking [18]. In the present analysis, however, exsmokers in general had the same probability as nonsmokers of taking antiasthmatic medication. Smokers are also more likely to have respiratory symptoms because of chronic obstructive lung disease, even though a large excess is not likely in the age group studied. Doctors may be more reluctant to introduce antiasthmatics for symptomatic smokers and instead concentrate on smoking cessation. The therapeutic effect of inhaled steroids has also been found to be decreased in smokers [19], which may make smokers less likely to continue taking this kind of asthma therapy. In accordance with the present analysis, it has been reported in an Australian study that even after being diagnosed as having asthma, smokers are more likely to be undertreated [20].

Age was not found to affect the probability of taking antiasthmatic medication, except in Iceland. This may be due to the fact that a fairly young population was studied, as other authors have found that the use of antiasthmatic drugs increases after the age of 50 yrs $[21,22]$. In some of the countries females were more likely to be using medication against asthma than were males with comparable levels of symptoms and BHR. This is in accordance with a Canadian study that found that females were more inclined to seek emergency treatment for acute asthma [23]. Results from previous studies have shown conflicting results concerning sex differences in the use of antiasthmatic drugs. Hallas and Hansen [24] analysed data from a Danish pharmacoepidemiological database of 20-44 yr old subjects. They found that $60 \%$ of those that had been prescribed asthma drugs were females. No sex difference concerning the utilization of antiasthmatic medication was found in a Swedish cross-sectional study [25], whereas in the UK ROBERTS and BATEMAN [26] found that males were more likely than females to have been prescribed inhaled antiasthmatic medication.

Table 4. - Antiasthmatic medication, physician-diagnosed asthma and doctor consultations within the last 12 months (\%) in nonsmoking (NS) and smoking (S) subjects with at least three respiratory symptoms in the last 12 months

\begin{tabular}{|c|c|c|c|c|c|c|c|}
\hline \multirow[t]{2}{*}{ Country } & \multirow[t]{2}{*}{$\mathrm{n}$} & \multicolumn{2}{|c|}{ Medication } & \multicolumn{2}{|c|}{ Asthma diagnosis } & \multicolumn{2}{|c|}{ Doctor consultation } \\
\hline & & NS & $\mathrm{S}$ & $\mathrm{NS}$ & $\mathrm{S}$ & NS & $\mathrm{S}$ \\
\hline Iceland & 25 & 63 & $14 *$ & 63 & $8 * *$ & 27 & 36 \\
\hline Norway & 62 & 37 & 19 & 47 & 29 & 26 & 21 \\
\hline Sweden & 129 & 64 & $24 * * *$ & 58 & $39 * *$ & 38 & $21 *$ \\
\hline Ireland & 69 & 45 & $15^{* *}$ & 45 & $13 * *$ & 32 & 28 \\
\hline UK & 151 & 68 & $43 * *$ & 63 & $44 *$ & 48 & 42 \\
\hline Germany & 117 & 45 & $26^{*}$ & 38 & 25 & 51 & 35 \\
\hline Netherlands & 102 & 47 & 34 & 30 & 24 & 28 & 40 \\
\hline Belgium & 92 & 45 & $23^{*}$ & 28 & 19 & 40 & 27 \\
\hline France & 243 & 47 & $25 * * *$ & 67 & $35 * * *$ & 60 & $34 * * *$ \\
\hline Spain & 124 & 44 & $10 * * *$ & 40 & $10 * * *$ & 29 & $5 * * *$ \\
\hline Italy & 30 & 54 & 41 & 77 & $31 *$ & 46 & 35 \\
\hline USA & 62 & 48 & 40 & 70 & $32 * *$ & 38 & 30 \\
\hline New Zealand & 185 & 60 & $34 * * *$ & 61 & $36 * *$ & 42 & 37 \\
\hline Australia & 106 & 64 & $31 * * *$ & 68 & $26 * * *$ & 46 & 34 \\
\hline
\end{tabular}


Table 5. - Antiasthmatic medication in nonsmoking (NS) and smoking (S) subjects with physiciandiagnosed asthma or subjects who consulted a doctor within the last 12 months because of breathing problems

\begin{tabular}{|c|c|c|c|c|c|c|}
\hline \multirow[t]{2}{*}{ Country } & \multirow[t]{2}{*}{$\mathrm{n}$} & \multicolumn{2}{|c|}{ Asthma diagnosis \% } & \multirow[t]{2}{*}{$\mathrm{n}$} & \multicolumn{2}{|c|}{ Doctor consultation $\%$} \\
\hline & & NS & $\mathrm{S}$ & & $\mathrm{NS}$ & $\mathrm{S}$ \\
\hline Iceland & 16 & 54 & 67 & 28 & 24 & 18 \\
\hline Norway & 44 & 53 & 44 & 29 & 54 & 38 \\
\hline Sweden & 102 & 75 & 67 & 90 & 58 & 55 \\
\hline Ireland & 24 & 75 & 75 & 33 & 62 & 35 \\
\hline UK & 100 & 81 & 77 & 109 & 65 & 48 \\
\hline Germany & 62 & 60 & 56 & 125 & 41 & 38 \\
\hline Netherlands & 43 & 68 & 53 & 77 & 54 & 40 \\
\hline Belgium & 42 & 67 & 61 & 97 & 29 & 41 \\
\hline France & 224 & 66 & $45 * *$ & 211 & 50 & 38 \\
\hline Spain & 48 & 70 & $29 * *$ & 62 & 52 & $17 * *$ \\
\hline Italy & 48 & 53 & 44 & 58 & 53 & 44 \\
\hline USA & 57 & 59 & 62 & 50 & 56 & 54 \\
\hline New Zealand & 148 & 76 & 66 & 117 & 65 & 56 \\
\hline Australia & 88 & 69 & $41 *$ & 100 & 63 & $35^{*}$ \\
\hline
\end{tabular}

The cost paid by the individual patient may also be a factor that influences the likelihood of using a drug. In most countries in this analysis antiasthmatic drugs were subsidised by public social insurance. In some countries, such as Germany, New Zealand and the UK, the patient paid a fixed price for each prescribed drug, while in other countries, such as Italy, France and Spain, the patients paid a proportion of the actual cost. In Australia, the Netherlands and Sweden the public insurance covered all of the cost for antiasthmatic drugs while in the USA the size of the subsidy depended on the subjects private insurance. Despite this, socioeconomic status did not affect the probability of taking antiasthmatics in any of the countries studied. In this respect the present results are in accordance with those of Strachan et al. [27], who found that antiasthmatic drug treatment was unrelated to socioeconomic status in a study on 5-17 yr old children. As the number of subjects in each country was limited, however, a simplified classification had to be used and this may have decreased the possibility of detecting an association between socioeconomic status and medication.

Since the early 1990s international guidelines for the management of asthma have emphasized that asthma is an inflammatory disease and that anti-inflammatory treatment is a first-line treatment for asthma [28, 29]. Therefore, the use of this particular group of antiasthmatics was analysed. In general, the results were similar to the previous analysis, with a positive relation to the level of asthma symptoms, BHR, atopy and female sex and a negative association with current smoking. The confidence intervals of the estimates, however, were wide, owing to the limited number of subjects and the fairly low prevalence of use of anti-inflammatory drugs in most countries.

The analysis of how personal and asthma-related variables influenced individual drug utilization was carried out by country. Combining data from all countries would have increased the power of the study. The result of such an analysis would, however, have been difficult to interpret, as there were large variations between countries in the associations between some independent variables and the individual use of antiasthmatic medication. No such variation was observed between centres within countries. In several countries the number of subjects investigated was fairly limited, which reduced the power to detect signifi- cant associations. One problem when interpreting the data is that there was a wide variation in response rate. It is unlikely however, that the observed associations were related to the variation in response rates. For example, smoking was negatively associated with medication in both a country with a high response rate, such as Sweden, and a country with a lower response rate such as France. It should also be noted that the results were only based on self-reported drug use and that the same limitation applies to the smoking data.

In conclusion, in many countries smokers were less likely to be using antiasthmatic drugs than were nonsmokers with comparable levels of symptoms and bronchial hyperresponsiveness. Age and socioeconomic status were in most countries, unrelated to medication, while in some countries females were more likely than males to use antiasthmatic medication.

\section{List of principal participants:}

Co-ordinating centre (London): P. Burney, S. Chinn, C. Luczynska, D. Jarvis, E. Lai.

Project Management Group: P. Burney (Project leader), S. Chinn, C. Luczynska, D. Jarvis, P. Vermeire (Antwerp), J. Bousquet (Montpellier), D. Nowak (Hamburg), J. Prichard (Dublin), R. de Marco (Verona), B. Rijcken (Groningen), J. Anto (Barcelona), J. Alves (Oporto), G. Boman (Uppsala), H. Kesteloot (Leuven), N. Nielsen (Copenhagen), P. Paoletti (Pisa). Participating centres: Austria: W. Popp (Vienna), Australia: M. Abramson, J. Kutin (Melbourne), Belgium: P. Vermeire, F. van Bastelaer (Antwerp South, Antwerp Central), Estonia: R. Jögi (Tartu), Denmark: M.B. Christiansen, M. Iversen (Aarhus), France: J. Bousquet (Montpellier), F. Neukirch, R. Liard (Paris), I. Pin, C. Pison (Grenoble), A. Taytard (Bordeaux), Germany: H. Magnussen, D. Nowak (Hamburg), H.E. Wichmann, J. Heinrich (Erfurt), Greece: N. Papageorgiou, P. Avarlis, M. Gaga, C. Marossis (Athens), Iceland: T. Gislason, D. Gislason (Reykjavik), India: R. Chowgule (Bombay), Ireland: J. Prich-ard, S. Allwright, D. MacLeod (Dublin), Italy: M. Bugiani, C. Bucca, C. Romano (Turin), R. de Marco, V. Lo Cascio, C. Campello (Verona), A. Marinoni, I. Cerveri, L. Casali (Pavia), The Netherlands: B. Rijcken, A. Kremer (Groningen, Bergen-op-Zoom, Geleen); New Zealand: J. Crane, S. Lewis (Wellington, Christchurch, Hawkes Bay), Norway: A. Gulsvik, E. Omenaas (Bergen), Portugal: C. Loureiro, C. Chieira, R. Cordeiro (Coimbra), J.A. Marques, J. Alves (Oporto), Spain: J. Anto, J. Castellsague, J. Sunyer, J. Soriano, M. Galobardes J. Roca A. Tobias (Barcelona), N. Muniozguren, J. Ramos González, A. Capelaste- gui (Galdakao), J. Castillo, J. Rodriguez Portal (Seville), 
J. Martinez-Moratalla, E. Almar (Albacete), J. Maldonado Pérez, A. Pereira, J. Sánchez (Huelva), J. Quiros, I. Huerta (Oviedo), Sweden: G. Boman, C. Janson, E. Björnsson (Uppsala), L. Rosenhall, E. Norrman, B. Lundbäck (Umeå), N. Lindholm, P. Plaschke (Göteborg), Switzerland: U. AckermannLiebrich, N. Künzli, A. Perruchoud (Basel), UK: M. Burr, J. Layzell (Caerphilly), R. Hall (Ipswich), B. Harrison (Norwich), J. Stark (Cambridge), USA: S. Buist, W. Vollmer, M. Osborne (Portland)

Acknowledgements: The co-ordination of this work was supported by the European Commission and the authors are grateful to the late C. Baya and M. Hallen for their help during the study and to K. Vuylsteek and the members of the COMAC for their support. The following grants helped to fund the local studies: Australia: Allen and Hanbury's, Australia. Belgium: Belgian Science Policy Office, National Fund for Scientific Research; France: Ministère de la Santè, Glaxo France, Institute Pneumologique d'Aquitaine, Contrat de Plan Etat-Region Languedoc-Roussillon, CNMATS, CNMRT (90MR/10, 91AF/6), Ministre Dèlègue de la Santè, RNSP; Germany: GSF and the Bundesminister fur Forschung und Technologie, Bonn. Greece: Greek Secretary General of Research and Technology, Fisons, Astra and Boehringer-Ingelheim. Italy: Ministero dell'Universita e della Ricerca Scientifica e Tecnologica, CNR, Regione Veneto grant RSF no. 381/05.93; New Zealand: Asthma Foundation of New Zealand, Lotteries Grant Board, Health Research Council of New Zealand. Norway: Norwegian Research Council project no. 101422/310. Portugal: Glaxo Farmacêutica Lda, Sandoz Portugesa; Spain: Ministero Sanidad y Consumo FIS grants no. 91/0016060/00E-05E, 92/0319, 93/0393, Hospital General de Albacete, Hospital General Juan Ramón Jiménenz, Consejeria de Sanidad Principado de Asturias; Sweden: Swedish Medical Research Council, the Swedish Heart Lung Foundation, Swedish Association against Asthma and Allergy, Swedish Society of Medicine, Astra, Glaxo-Wellcome, Boehringer-Ingelheim; Switzerland: Swiss National Science Foundation grant 4026-28099. UK: National Asthma Campaign, British Lung Foundation, Department of Health, South Thames Regional Health Authority. USA: United States Dept. of Health, Education and Welfare Public Health Service grant no.2 S07 RR05521-28.

\section{References}

1. Burney PGJ, Luczynska C, Chinn S, Jarvis D. The European Community Respiratory Health Survey. Eur Respir J 1994; 7: 954-960.

2. United Medical and Dental Schools of Guy's and St Thomas's Hospitals. Department of Public Health Medicine. London, protocol for the European Community Respiratory Health Survey, 1993.

3. European Community Respiratory Health Survey. The prevalence of respiratory symptoms in the European Community Respiratory Health Survey (ECRHS). Eur Respir J 1996; 9: 687-695.

4. European Community Respiratory Health Survey. The distribution of total and specific serum IgE in the European Community Respiratory Health Survey. J Allergy Clin Immunol 1997; 99: 314-322.

5. European Community Respiratory Health Survey. Variation in bronchial responsiveness in the European Community Health Survey. Eur Respir J 1997; 10: 2495-2501.

6. European Community Respiratory Health Survey. Physician diagnosed asthma and drug utilization in the European Community Respiratory Health Survey. Eur Respir J 1997; 10: 1795-1802.

7. Nordic Council on Medicines. Nordic Statistics on Medicines 1990-1992. Upsala NLN publication No 34, 1993.

8. Kesten S, Rebuck AS, Chapman KR. Trends in asthma and chronic obstructive therapy in Canada 1985 to 1990. J Allergy Clin Immunol 1993; 92: 499-506.

9. Sly RM. Changing asthma mortality and sales of inhaled bronchodilators and antiasthmatic drugs. Ann Allergy 1994; 73: 439-443.

10. Van Ganse E, Van der Linden PD, Leufkens HGM, Herings RMC, Vincken W, Ernst P. Asthma medication and disease exacerbations; an epidemiological study as a method for asthma surveillance. Eur Respir J 1995; 8: 18561860.

11. Ruggieri F, Hindle M. Diagnosis and treatment of asthma across Europe. Eur Respir J 1989; 2: Suppl. 6, 536s-539s.

12. Vermeire P. Differences in asthma management around the world. Eur Respir Rev 1994; 4: 279-281

13. Björnsson E, Janson C, Håkansson L, Enander I, Venge P, Boman G. Serum eosinophil cationic protein in relation to bronchial asthma in a young Swedish population. Allergy 1994; 49: 730-736.

14. Janson C, De Backer W, Gislason T, et al. Increased prevalence of sleep disturbances and daytime sleepiness in subjects with bronchial asthma: a population study of young adults in three European countries. Eur Respir J 1996; 9: 2132-2138.

15. European Community for Coal and Steel. Standardization of lung function tests. Clin Respir Phys 1983; 19: Suppl. 5: 22-27.

16. Classification of Occupations 1980. Office of Population Censuses and Surveys. London, Her Majesty's Stationery Office, 1980.

17. Francis B, Green M, Payne C, eds. The GLIM system release 4 manual. Oxford, Clarendon Press, 1993.

18. Troisi RJ, Speizer FE, Rosner B, Trichopondos D, Willett WC. Cigarette smoking and incidence of chronic bronchitis and asthma in women. Chest 1995; 108: 1557-1561.

19. Pedersen B, Dahl R, Karlström R, Peterson CGB, Venge P. Eosinophil and neutrophil activity in asthma in a oneyear trial with inhaled budesonide. The impact of smoking. Am J Respir Crit Care Med 1996; 153: 1519-1529.

20. Gibson P, Henry D, Francis L, et al. Association between availability of non-prescription beta2-agonist inhalers and under treatment of asthma. BMJ 1993; 306: 1514-1518.

21. Boëthius G. Utilization of anti-asthmatic drugs in Sweden: review of sales and prescription data 1975-1991. In: Strandberg K, Beerman B, Lönnerholm G, eds. Pharmacological Treatment of Bronchial Asthma. Uppsala Swedish Medical Products Agency, 1993; pp. 7-17.

22. Gislason T, Olafsson O, Sigvaldason A. Users of anti asthma drugs in Iceland: a drug utilization study. Eur Respir J 1997; 10: 1230-1234.

23. Awadh N, Chu S, Grunfeld A, Simpson K, FitzGerald JM. Comparison of males and females presenting with acute asthma to the emergency department. Respir Med 1996; 90: 485-489.

24. Halras J, Hansen N-C G. Individual utilization of antiasthma medication by young adults: a prescription database analysis. J Intern Med 1993; 234: 65-70.

25. Larsson L, Boethius B, Uddenfeldt M. Differences in utilization of asthma drugs between two neighbouring Swedish provinces: relation to symptom reporting. Eur Respir J 1993; 6: 198-203.

26. Roberts SJ, Bateman DN. Which patients are prescribed inhaled anti-asthma drugs? Thorax 1994; 49: 1090-1095.

27. Strachan DP, Anderson HR, Limb ES, O'Neill AO, Wells N. A national survey of asthma prevalence, severity and treatment in Great Britain. Arch Dis Child 1994; 70: 174 178.

28. National Heart, Lung, and Blood Institute, National Institute of Health. International Consensus Report on the diagnosis and management of asthma. NIH publication number 92-3091, 1992.

29. National Institute of Health, National Heart, Lung, and Blood Institute. Global Initiative for asthma. NIH publication number 95-3659, 1995. 